\title{
原発性肺癌における ${ }^{201} \mathrm{TI} /{ }^{67} \mathrm{Ga}$ 粗摂取率比と 組織型との関連
}

\author{
${ }^{201} \mathrm{Tl}$ to ${ }^{67} \mathrm{Ga}$ Crude Uptake Ratio in Primary Lung Cancer \\ with Reference to Histological Type
}

戸川貴史 · 鈴木 晃・樋口義典 $\cdot$ 加藤和夫 · 小林克子 · 木村和衛 ${ }^{*}$

\begin{abstract}
要旨：肺癌への ${ }^{201} \mathrm{Tl} と^{67} \mathrm{Ga}$ の摂取差を定量的に評価するため, 40例の原発性肺癌において ${ }^{201} \mathrm{Tl}$ $と^{67} \mathrm{Ga}$ の摂取比を比較検討した。 その結果, 腺癌と類表皮癌では ${ }^{201} \mathrm{Tl}{ }^{67} \mathrm{Ga}$ の摂取が相 反した。燕麦細胞癌は類表皮癌に類似した捸取を示し, 一方, 腺扁平上皮癌は腺癌と類 表皮癌の中間に位置する捸取を示した．以上の結果より， ${ }^{201} \mathrm{Tl}{ }^{67} \mathrm{Ga}$ の捸取能の比較に よる肺癌の核医学的分類の可能性が明らかとなった.
\end{abstract}

〔肺癌 $25(2): 187 \sim 195,1985$ 〕

Key words : ${ }^{201} \mathrm{Tl}$-chloride, ${ }^{67} \mathrm{Ga}$-citrate, Lung cancer.

\section{はじめに}

肺癌は多彩な生物学的性質を有しているが, 組織型の差はその予後を決定する重要な因子と されている!)しかし, 組織型のみでは肺癌の多 彩な増殖性, 進展様式を充分解明し得ない場合 もあり, 最近では組織構築と腫瘍細胞の生化学 的, 生物学的性質との関連性が種々の観点から 検討されている2) 4)

肺癌の核医学的診断は, 腫瘍細胞が特殊な卜 レーサーを機能的に捸取する状態を基盤にして おり,この攝取を介して肺癌の生化学的性質を 画像として把握することを可能にしている． ${ }^{67}$ Ga-citrate ${ }^{5}$ は肺癌の核医学診断に大きな進歩 をもたらした。 ${ }^{201} \mathrm{Tl}$-chloride ${ }^{6)}$ も腫瘍親和性核 種として知られているが, 肺癌に関する臨床的 評価は高くなかった。しかし, ${ }^{67} \mathrm{Ga}$ と ${ }^{201} \mathrm{~T} 1 の$ 腫 瘍集積機序は異なるとされ?)さらに肺癌への両

福島県立医科大学核医学教室

$*$ 同 放射線科学教室
核種の捸取は症例により差を認めることから, 両核種の摂取能を定量的に比較検討することに より, 肺癌の核医学的分類の可能性が考えられ た.

\section{対象および方法}

${ }^{201} \mathrm{Tl}$ と ${ }^{67} \mathrm{Ga}$ スキンは昭和56年10月より昭 和 58 年 12 月までに福島医大附属病院核医学科お よび放射線科において83例の肺腫瘍疾患に対し て行われた。このうち, 組織型が確定した未治 療の原発性肺癌で, かつ ${ }^{201} \mathrm{Tl}$ と $^{67} \mathrm{Ga}$ スキャンの 定量的評価が可能であった40例を対象とした (Table 1).すなわち, ${ }^{201} \mathrm{Tl},{ }^{67} \mathrm{Ga}$ スキャンのい ずれにおいても, 病巣に一致した異常集積像を 認め, 病巣部に対する関心領域 (region of interest：ROI)の設定が可能であった症例について のみ定量的評価を行った。また, 病巣が肝臟あ るいは心臓と重複しているためにROIの設定が 行えず，正確な摂取率の測定が期待し得ない症 
Table 1. 40 lung cancer cases.

\begin{tabular}{llr}
\hline 1) Sex & Male & 25 \\
& Female & 15 \\
2) Age & 43 to 86 (Mean 68 yrs. & \\
3) Histological type & Adenocarcinoma & 17 \\
& Epidermoid carcinoma & 14 \\
& Small cell carcinoma & 7 \\
& Oat cell type & 3 \\
& Intermediate cell type & 4 \\
& Adenosquamous carcinoma & 2 \\
4) Clinical stage & I & 7 \\
& II & 2 \\
& III & 12 \\
& TBLB & 19 \\
5) Method of definitive & 18 \\
Diagnosis & Surgery & 10 \\
& Cytological examination & 9 \\
& Autopsy & 3
\end{tabular}

TBLB : Transbronchial lung biopsy

例も対象上り除外した。男性は25名，女性は 15 名で，平均年令は68才であった。組織型は腺癌 が17例と最も多く，次いで類表皮癌14例，小細 胞癌 7 例 (燕麦細胞型 3 例, 中間細胞型 4 例), 腺扁平上皮癌 2 例であった。臨床病期はUICC. TNM分類 (1978年) に基づき分類した. stageIV が19例と最も多く, stageIIIは12例, stage I は 7 例, stage II は 2 例であった。組織型の判定は経 気管支肺生検によるものが18例と最も多く, 手 術によるもの10例, 喀痰あるいは擦過細胞診に よるもの 9 例, 剖検によるものは 3 例であった。

${ }^{201} \mathrm{Tl}$ スャンは, ${ }^{201} \mathrm{Tl}$-chloride $2 \mathrm{mCi}$ 患者 に静注後30分より胸部前面像と後面像とをガン マカメラ(GCA 401-5) にて撮像した。同時に画 像を $128 \times 128$ のトリックスにてデー夕処理装

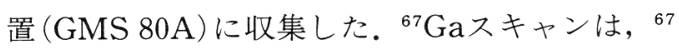
Ga-citrateを201 Tlスキャンの 7 日後に $2 \mathrm{mCi}$ 静 注し, 静注後 48 時間より胸部前面像と後面像を 撮像し同様の画像収集を行った。 ${ }^{201} \mathrm{Tl}$ では低工 ネルギー用コリメータ（RDC-43A）を使用し，フ オトピークは $80 \mathrm{KeV} \pm 20 \%$ とし， ${ }^{67} \mathrm{Ga}$ では中エ ネルギー用コリメー夕 $(\mathrm{RDH}-54 \mathrm{~A})$ を使用し, フ オトピークを $93 \mathrm{KeV} \pm 20 \%, 184 \mathrm{KeV} \pm 20 \%$ と し，いずれも preset countを400K countに設定
Fig. 1. The measurement of the crude uptake ratio (CUR) of $201 \mathrm{~T} 1$ to $67 \mathrm{Ga}$ on the same patient.

After regions of interest (ROIs) were set on the tumor and the normal lung, the mean counts ( $\mathrm{T}$ : at the tumor, N; at the normal lung) for ROIs were measured and the CUR of $201 \mathrm{~T} 1$ to $67 \mathrm{Ga}$ was obtained by calculating the ratio of both crude uptakes (Crude Uptake: T-N/N).

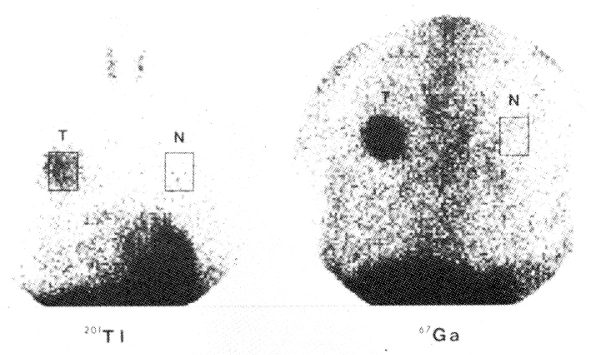

し撮像した.

両スキャンの攝取率の定量的評価は, 前面像 と後面像とを比較し病巣がより明瞭に陽性描画 されている画像にて行った。 Fig. 1 に示した如 く腫瘍部と健常肺野にROIを設定し, ROI内の 平均カウント数 (それぞれ $\mathrm{T}, \mathrm{N}$ )を計測した後, 両スキャンともに $\mathrm{T}-\mathrm{N} / \mathrm{N}$ を腫瘍への ${ }^{201} \mathrm{~T} 1$ ある いは ${ }^{67} \mathrm{Ga}$ 粗摂取率 (crude uptake：CU)とした。 さらに, 同一症例において ${ }^{201} \mathrm{~T} 1$ 粗摂取率と ${ }^{67} \mathrm{Ga}$ 粗摂取率とを比較するため粗摂取率比 (crude uptake ratio: CUR)を求めた. CURはCU(201 $\mathrm{Tl}) / \mathrm{CU}\left({ }^{67} \mathrm{Ga}\right)$ として計算した。

\section{結 果}

同一症例に扮いて ${ }^{201} \mathrm{Tl} /{ }^{67} \mathrm{Ga}$ のCURを求め, 各組織型別に比較した(Table 2$)$.

CURは腺癌で 1.82 と高值を示し, 類表皮癌で は0.41であり腺癌に比し有意に低值を示した ( $\mathrm{p}<0.001)$. 燕麦細胞癌のCURは0.40であり 腺癌に比し有意に低值を示し $(\mathrm{p}<0.001)$, 燕麦 細胞癌は類表皮癌に類似した摄取能を示した。 中間細胞癌では標準偏差が1.91と大であり一定 の傾向を認めなかった。一方, 腺扁平上皮癌の CURは0.95であり, 腺癌と類表皮癌の中間值を 
Table 2. Crude uptake ratio of $201 \mathrm{~T} 1$ to $67 \mathrm{Ga}$ in lung cancer.

\begin{tabular}{lcl}
\hline & Cases & CUR \\
\hline Adenocarcinoma & 17 & $1.82 \pm 1.27$ \\
Epidermoid carcinoma & 14 & $0.41 \pm 0.25^{*}$ \\
Oat cell carcinoma & 3 & $0.40 \pm 0.07^{*}$ \\
Intermediate cell carcinoma & 4 & $1.46 \pm 1.91$ \\
Adenosquamous carcinoma & 2 & $0.95 \pm 0.19$ \\
\hline
\end{tabular}

CUR : Crude uptake ratio of ${ }^{201} \mathrm{Tl}$ to ${ }^{67} \mathrm{Ga}$

* Statistically significant from adenocarcinoma $(\mathrm{p}<0.001)$ by Cochran Cox test

Fig. 2. Correlation between the CUR and histological types. The CUR varied from patient to patient and ranged from 0.03 to 4.89 . The patients were classified by the CUR into three groups: Group I (CUR $<0.80)$, Group II $(0.80 \leqq$ CUR $<$ 1.25 ), and Group III (CUR $\geqq 1.25$ ). Many epidermoid carcinomas and small cell carcinomas belonged to Group I, whereas many adenocarcinomas belonged to Group II or III.

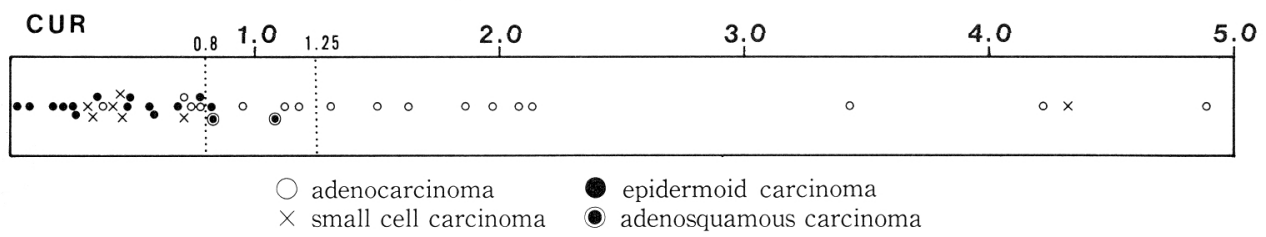

示した。

さらに, 各症例のCURを組織型別に比較した (Fig. 2).CURは症例により異なり，0.03から 4.89までに分布した。CURにより，肺癌を以下 の 3 群に分類することが可能であった。 I 群 は ${ }^{67} \mathrm{Ga}$ の摂取が201 $\mathrm{Tl}$ よりも高いもの $(\mathrm{CUR}<$ 0.80), II群は両核種の損取に顕著な差がないも の $(0.80 \leqq \mathrm{CUR}<1.25)$, III群は201 T1の攝取が67 $\mathrm{Ga}$ よも高いものである $(\mathrm{CUR} \geqq 1.25)$ 。組織 型別に比較すると, I 群23例中, 腺癌は 4 例の みで他はすべて類表皮癌や小細胞癌であった。 すなわち，類表皮癌や小細胞癌のほとんどは201 T1よりも ${ }^{67} \mathrm{Ga}$ をより多く攝取した。これに対 し，III群では11例中10例 (90.9\%)が腺癌であっ た.また, 腺癌 17 例中 12 例 $(70.6 \%)$ はCURが 1.0 より高値を示し, 腺癌の多くは ${ }^{67} \mathrm{Ga} り も{ }^{201} \mathrm{~T} 1$ をより多く摂取し, 類表皮癌や燕麦細胞癌とは 相反する搨取能を示した。II群では，腺癌が 3 例と最も多かったが，他には腺扁平上皮癌 2 例, 類表皮癌 1 例が含まれた。また, 腺癌 4 例は I 群に属し, 小細胞癌 (中間細胞型) 1 例はIII群に 属し, 組織学的には同一の腫瘍でも両核種の搨 取は症例により差を認めた。次に I 群とIII群の
Fig. 3, a. Chest roentgenogram of a 59-year-old man with a left hilar tumor.
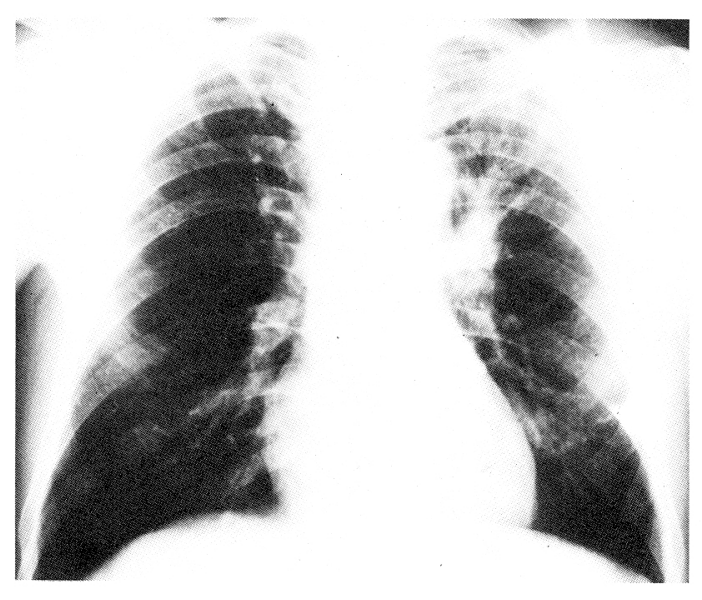

症例を示す。

症例 1 . 59才, 男性, $\mathrm{T}_{2} \mathrm{~N}_{1} \mathrm{M}_{1}$ 。

昭和56年10月，咳痰を主訴に当科を受診した。 胸部X線像では，左肺門部から左上肺野にかけ ての異常院影を認めた (Fig. 3,a).ファイバース コープによる気管支鏡検査では，左上区枝と左 舌区枝の腫瘍による狭窄像之, 左主気管支にお 
Fig. 3, b. $201 \mathrm{~T} 1$ (left) and $67 \mathrm{Ga}$ (right) scans show that the lesion is more definitely delineated with $67 \mathrm{Ga}$ than with $201 \mathrm{~T} 1$, and the CUR shows a low value of 0.18 .

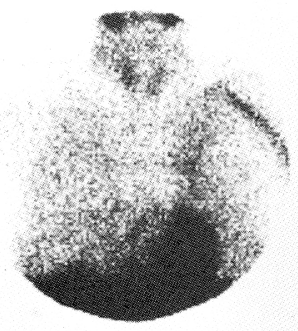

TL-201 ANT

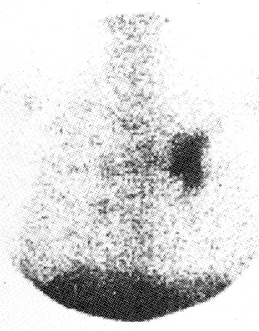

GA-67 PNT
Fig. 4.a. Chest roentgenogram of a 67-year-old woman whose tumor is seen in the right upper lung field.
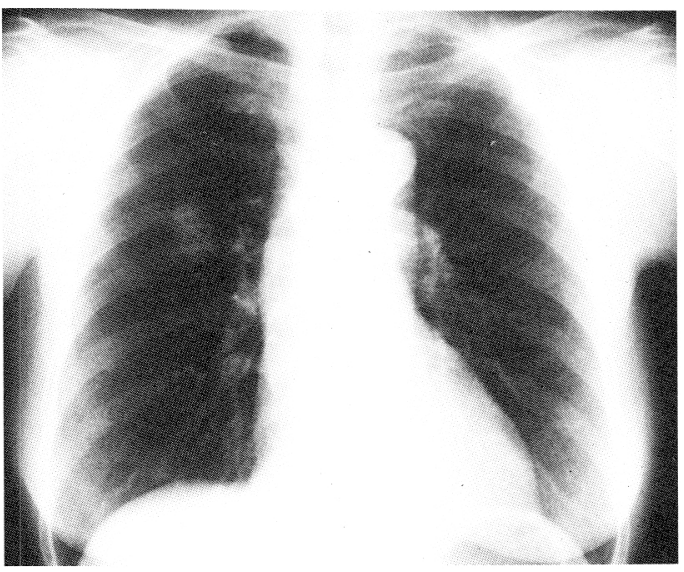

よぶ腫瘍浸潤像を認めた。 ${ }^{201} \mathrm{~T} 1$ と ${ }^{67} \mathrm{Ga}$ スャン を比較すると, 病巣は ${ }^{67} \mathrm{Ga}$ でより強く陽性描画 され(Fig. 3,b)，CURは0.18と低值を示した。経 気管支肺生検により低分化類表皮癌と診断され た(Fig. 3,c).

症例 2。67才，女性, $\mathrm{T}_{2} \mathrm{~N}_{0} \mathrm{M}_{0}$ 。

昭和57年 11 月, 胸部X線像にて右上葉の腫瘤影 を指摘された (Fig. 4,a)、 ${ }^{201} \mathrm{Tl} と^{67} \mathrm{Ga}$ スキン を比較すると，病巣は201T1でより明瞭に陽性描 画され，CURは3.43と高值を示した (Fig. 4,b). 経気管支肺生検により腺癌と診断され，昭和58 年 1 月右上葉切除術が行われた。組織学的には 高分化乳頭腺癌と診断された (Fig. 4,c).
Fig. 3, c. Photomicrograph representing poorly differentiated epidermoid carcinoma.

$$
\text { x } 200
$$

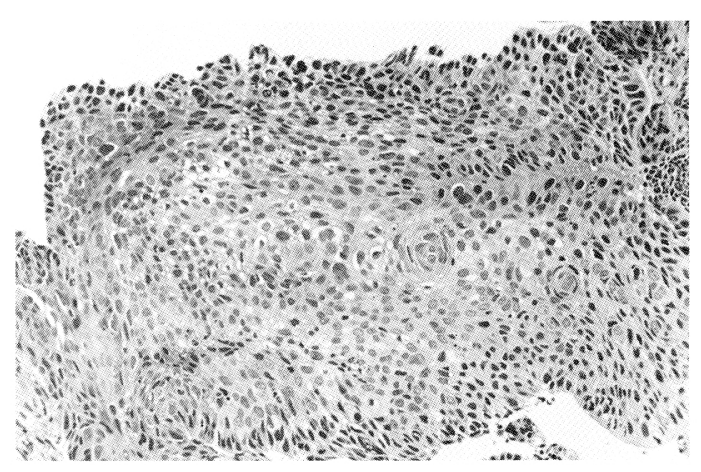

Fig. 4, b. $201 \mathrm{~T} 1$ (left) and $67 \mathrm{Ga}$ (right) scans show that the lesion is more definitely delineated with $201 \mathrm{~T} 1$ than with ${ }^{7} \mathrm{Ga}$, and the CUR shows a high value of 3.43 .
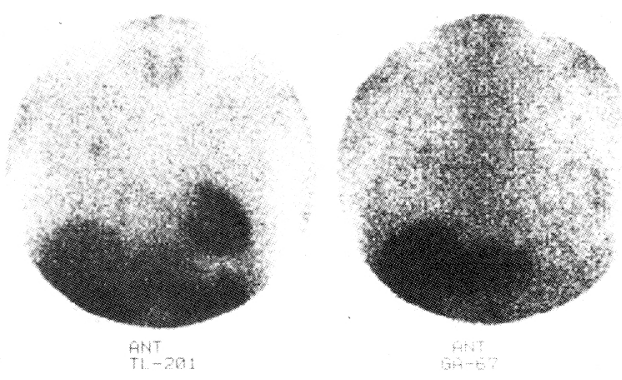

以上の結果より, 今回の方法による肺癌の核 医学的分類と従来の組織型分類との間には密接 な関連があることが明らかとなった。したがっ て, 粗摂取率比による肺癌組織型推定の正診度 を検討した。すなわち，CURが 0.80 以上を示し た場合 (II群またはIII群) は腺癌である，または CURが0.80未満を示した場合 ( I 群) は類表皮 癌あるいは小細胞癌であると核医学的に組織型 を推定した場合の正診度 (accuracy) をTable 3 に示した，腺癌での正診度は0.80であり，肺癌 の $80 \%$ は今回の診断法により腺癌であるか否か 診断可能であった。また，同様に肺癌の $85 \%$ は 類表皮癌あるいは小細胞癌であるか否か診断可 
Fig. 4,c. Photomicrograph representing well differentiated papillary adenocarcinoma.

x 200

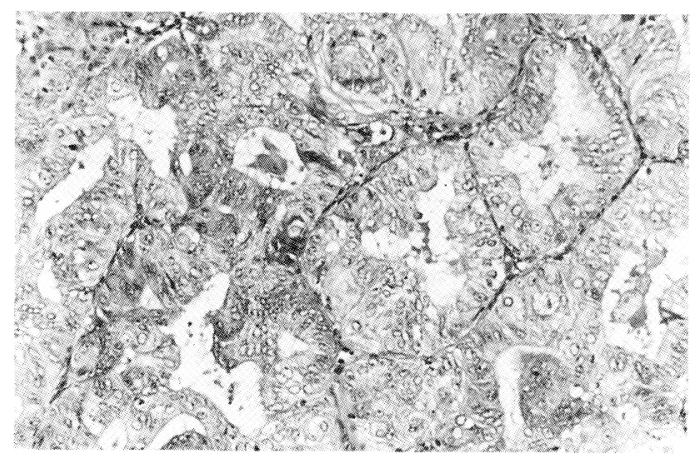

能であった。しかし，小細胞癌(燕麦細胞型)の CURは類表皮癌とほぼ同一值を示しており， CURによる両者の鑑別は不可能であった。

\section{考 察}

肺癌の核医学的診断は肺癌病巣とその転移巣 の検出を目的としているが, 現在, 核医学的に 検出可能な病巣の大きさには限界があり9)早期 診断としての価值は胸部X線像よりも少ない101 また，その確定診断に関しても，喀痰細胞診11) メトラゾンデによる末梢病巣擦過法, ${ }^{12}$ 経気管支 肺生検 ${ }^{13)}$ 経皮的針生検 ${ }^{14)}$ 等を総合すると, 肺癌 の正診率は $90 \%$ 以上であり, 15)核医学診断は病巣 の拡がりやN因子の判定などの補助的なものと されてきた备しかし, 本来, 核医学的腫瘍診断 は特殊なトレーサーの腫瘍への機能的な捸取を 基本としているため，トレーサーの攝取を介し た肺癌の生化学的性質の評価が可能であると考 えられる。また，これらの摄取を定量化するこ とによって客観的評価が可能であることも核医 学診断の利点の一つであろう。本論文では, 201 $\mathrm{Tl}$ と ${ }^{67} \mathrm{Ga}$ の肺癌への摂取差を定量的に評価し， その結果をもとに肺癌の核医学的分類を試みた。 さらに，今回の方法による肺癌の核医学的分類 が従来の組織型分類とどの程度一致するかを検 討した。

${ }^{67} \mathrm{Ga}$-citrateは1969年, Edwardsと Hayes ${ }^{5)}$ の報告以来, 肺癌の診断にも広く用いられてい
Table 3. Accuracies in this quantitative $201 \mathrm{~T} 1$ and $67 \mathrm{Ga}$ scans.

\begin{tabular}{lcc}
\hline \multicolumn{1}{c}{$\begin{array}{c}\text { Disease } \\
\text { CUR }\end{array}$} & $\begin{array}{c}\text { Adenocarcinoma } \\
\geqq 0.80\end{array}$ & $\begin{array}{c}\text { Epidermoid carcinoma or } \\
\text { small cell carcinoma } \\
<0.80\end{array}$ \\
\hline $\mathrm{TP}$ & 13 & 19 \\
$\mathrm{FP}$ & 4 & 4 \\
$\mathrm{TN}$ & 19 & 15 \\
$\mathrm{FN}$ & 4 & 2 \\
Positive pre- & 0.76 & 0.83 \\
dictive value & & 0.88 \\
$\begin{array}{l}\text { Negative pre- } \\
\text { dictive value }\end{array}$ & 0.83 & 0.90 \\
Sensitivity & 0.76 & 0.79 \\
Specificity & 0.83 & 0.85 \\
Accuracy & 0.80 & \\
\hline
\end{tabular}

TP : True positive FP : False positive TN : True negative FN : False negative Postitive predictive value: $\mathrm{TP} /(\mathrm{TP}+\mathrm{FP})$ Negative predictive value: $\mathrm{TN} /(\mathrm{TN}+\mathrm{FN})$ Sensitivity: $\mathrm{TP} /(\mathrm{TP}+\mathrm{FN}) \quad$ Specificity : $\mathrm{TN} /(\mathrm{TN}+\mathrm{FP})$ Accuracy : $(\mathrm{TP}+\mathrm{TN}) /(\mathrm{TP}+\mathrm{FP}+\mathrm{TN}+\mathrm{FN})$

る。一方， ${ }^{201} \mathrm{~T} 1$-chlorideは心筋スキャン製剤と して知られているが，腫陽スキャン製剤として の可能性が1976年, Cox, Salvatore ${ }^{17)}$ らによ て報告された。しかし，肺癌診断に扔ける ${ }^{201} \mathrm{Tl}$ の有用性は ${ }^{67} \mathrm{Ga}$ 治調されていない18)肺癌の 検出率に限れば ${ }^{01} \mathrm{~T} 1{ }^{67} \mathrm{Ga}$ に劣らないが, ${ }^{8)}$ 吕肺 癌への ${ }^{201} \mathrm{~T} 1 の$ 集積程度が ${ }^{67} \mathrm{Ga}$ よも低く, ${ }^{67} \mathrm{Ga}$ ほど明瞭に病巣が陽性描画されない8)ことがそ の主たる理由とされている。VX-2 $2^{20)}$ や吉田肉腫 ${ }^{211}$ を用いた基礎的検討でも， ${ }^{201} \mathrm{~T} 1$ の腫瘍集積は 67 $\mathrm{Ga}$ よも低く,腫瘍スキャン製剤としての ${ }^{201} \mathrm{~T} 1$ の価值は少ないとされた。しかし,肺癌への ${ }^{67} \mathrm{Ga}$ の摂取は腺癌で低いという報告 ${ }^{22,23) や, ~}{ }^{201} \mathrm{Tl}$ で より明瞭に陽性描画される肺癌の報告8もをさ

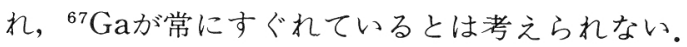
今回, ${ }^{201} \mathrm{Tl} と^{67} \mathrm{Ga}$ の摂取を定量的に比較した結 果では，40例中 26 例 $(65.0 \%)$ で67 $\mathrm{Ga}$ の捸取が201 T1よりも高く, 14例(35.0\%)では逆に ${ }^{201} \mathrm{~T} 1 の$ 攝 取がより高く，両核種の搨取は症例により差を 認めると結論される。

現在まで， ${ }^{67} \mathrm{Ga}$ 摂取率の定量化に関する報告 はいくつかあり, 類表皮癌や未分化癌に比し腺

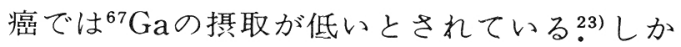


し, ${ }^{67} \mathrm{Ga}$ 単独による摂取率の定量的評価は ${ }^{67} \mathrm{Ga}$ を搨取する腫瘍の体積を正確に求めることが困 難であり，捸取率の正確な体積補正が期待でき ず，腫瘍の大きさが異なる場合攝取率の正確な 比較が行えないという久点を有している! 出これ に対して， ${ }^{201} \mathrm{~T} 1$ と ${ }^{67} \mathrm{Ga}$ の摂取率の比を求める今 回の方法は，同一腫瘍においての比較であるた め体積補正が不要であり，さらに ${ }^{201} \mathrm{~T} 1$ と ${ }^{67} \mathrm{Ga} の$ どちらがより多く摂取されているかを明確かつ 簡単に定量化することを可能にした，また，201 $\mathrm{T} 1$ と ${ }^{67} \mathrm{Ga}$ とではエネルギーピークが異なるた め, 両者の捸取率を求める場合, 深さの差に基 づく深部補正が必要となる。しかし, ファント 厶を用いた基礎的検討では24),25)201 $\mathrm{Tl} /{ }^{67} \mathrm{Ga}$ 粗捸 取率比は異なる深さにおいても一定であり正確 なパラメータであった。

粗摂取率比により肺癌を核医学的に分類する と, 肺癌は大きく 3 群に分類された。 今回は, 粗摂取率比の境界值を 0.80 と 1.25 によって分類 した。しかし，これらは勿論絶対的な值ではな く, 腫瘍が201T1をより多く摂取しているか, あ

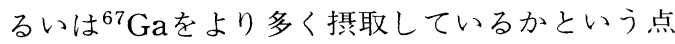
を考慮することが最も重要であろう，類表皮癌 の14例中 13 例 $(92.9 \%)$ と, 燕麦細胞癌は, 今回 検索した 3 例とも I 群に属し，これらは ${ }^{201} \mathrm{~T} 1 よ$

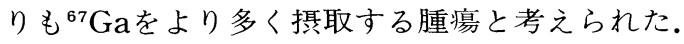
これに対して，III群では11例中 10 例が腺癌であ

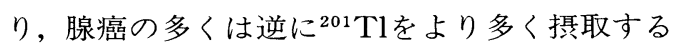
腫瘍であった。したがって，類表皮癌や燕麦細 胞癌と腺癌とでは ${ }^{201} \mathrm{Tl}$ と $^{67} \mathrm{Ga}$ の摂取が相反し, 粗摂取率比からもこれらは異なる生化学的性質 を有する腫瘍と考えられた。また，腺扁平上皮 癌の粗摂取率比は腺癌と類表皮癌の中間值を示 しており，粗捸取率比は肺癌の組織型の差を明 確に反映していた。

${ }^{201} \mathrm{Tl}{ }^{67} \mathrm{Ga}$ 腫瘍親和性の差は，これらの腫 痬集積機序の差に基づいているものと考えられ る. ${ }^{201} \mathrm{~T} 1$ の腫瘍集積には腫瘍のカリウム代謝が 関連のあることをItoら ${ }^{20)}$ は指摘したが, 悪性腫 瘍の中でカリウムが高值のものがあることは以 前より知られていた26),27)また, Muranaka7)は腫 瘍への ${ }^{201} \mathrm{~T} 1 の$ 搨取がウアバインによって阻害
されることから， ${ }^{201} \mathrm{~T} 1$ の腫瘍集積にはカリウム と同様に $\mathrm{Na}^{+}-\mathrm{K}^{+}-\mathrm{ATPase}$ 含む能動輸送が関 与していると考察している. したがって, ${ }^{201} \mathrm{Tl}$ の集積は腫瘍組織中のカリウムの量的差，ある いはカリウム代謝の差を反映していると考えら れる。

一方， ${ }^{67} \mathrm{Ga}$ の腫瘍集積に関しては， ${ }^{67} \mathrm{Gaがト}$ ランスフェリンと結合しトランスフェリンリセ プターを介して腫痬内に転入するとするもの や28)トランスフェリンとは結合しないかあるい はゆるく結合している ${ }^{67} \mathrm{Ga}$ が集積に関与してい る29)等, 現在まで数多くの報告があるが未だ充 分解明されていない.しかし， ${ }^{67} \mathrm{Ga}{ }^{201} \mathrm{Tl}$ と同 様に周期律第III A 族の金属であり， ${ }^{67} \mathrm{Ga}$ 集積が 腫瘍中の金属代謝を反映している可能性は充分 考えられる。したがって, ${ }^{201} \mathrm{Tl} /{ }^{67} \mathrm{Ga}$ の粗搨取率 比による肺癌の定量的診断は, 肺癌組織中の金 属代謝の量的差を表現しているとも考えられ， 肺癌の生化学的性質の一面を評価していると言 える.すなわち，腫瘍組織中にカリウムなどの 金属代謝の量的差が存在すれば201 $\mathrm{T} 1$ と $^{67} \mathrm{Ga} の$ 捸取は異なってくるものと考えられ， ${ }^{201} \mathrm{~T} 1$ の捸 取が高い腫瘍すなわち腺癌では, 腫瘍内力リウ ム代謝が他の組織型よりも高いことが予想される。

さらに，粗捸取率比が類表皮癌，腺扁平上皮 癌, 腺癌の順に低值から高值へと連続的に移行 したことは, 腺扁平上皮癌の組織発生様式を示 唆するものであった。すなわち，各組織型を単 にそれぞれ異なるものとしてとらえるのではな く，粗摂取率比からはこれらを一連の連続する 腫瘍系として評価することによって，多彩な肺 癌の発生様式と分化過程を推測する上でも貴重 な情報を定量的に得ることが可能となった。

\section{結 語}

原発性肺癌40例において, ${ }^{201} \mathrm{Tl} /{ }^{67} \mathrm{Ga}$ 粗摂取 率比を求め, 肺癌の定量的評価の可能性を検討 した。

1） ${ }^{201} \mathrm{Tl} /{ }^{67} \mathrm{Ga}$ 粗捸取率比による肺癌の定量的 診断が可能であった。すなわち，粗摂取率比は 腺癌では 1.82 と高値を示し, 腺癌の多くは ${ }^{67} \mathrm{Ga}$

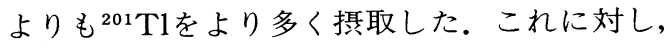


類表皮癌での粗摂取率比は 0.41 と腺癌に比し有 意に低值を示し $(\mathrm{p}<0.001)$ ，類表皮癌は ${ }^{201} \mathrm{~T} 1$ よりも ${ }^{67} \mathrm{Ga} よ り$ 多く摂取した。燕麦細胞癌の 粗摂取率比は $0.40 て ゙ あ り ，$ 腺癌に比し有意に低 值を示した $(\mathrm{p}<0.001)$ 。一方，腺扁平上皮癌で の粗摂取率比は0.95であり，腺癌と類表皮癌の 中間值を示し，粗摂取率比は組織型の差を明確 に反映していた。ささに，粗摂取率比からは， 肺癌を I 群 $(\mathrm{CUR}<0.80)$, II 群 $(0.80 \leqq \mathrm{CUR}<$ $1.25)$ ，およびIII群 (CUR $\geqq 1.25) の 3$ 群に分類 することが可能であった。類表皮癌14例中13例 と燕麦細胞癌 3 例は I 群に分類された。一方, 腺癌17例中 10 例はIII群に，3 例はII群に分類さ れた。粗捸取率比による肺癌組織型推定の正診 度は腺癌では $80 \%$ あっあた。

2 ) これらの粗摂取率比の差は肺癌組織中の 金属代謝，特にカリウム代謝の量的差に基づく
ものと考えられ，粗摂取率比は肺癌組織型の推 定を可能にしたのみでなく，腫瘍内金属代謝を 介した肺癌の生化学的性質を評価しているとも 考えられた。すなわち，腺癌では腫瘍内力リウ ム代謝が他の組織型に比し高いことが予測され た. さらに，類表皮癌，腺扁平上皮癌，腺癌で の粗摂取率比はそれぞれ連続的に低值から高值 へと移行しており，今回の分類ではこれらの組 織型を一連の連続する腫瘍として評価すること が可能であった，すなわち， ${ }^{201} \mathrm{Tl}{ }^{67} \mathrm{Ga}$ の摂取 動態よりみた肺癌の定量的診断は, 多彩な肺癌 の発生様式と分化過程をも示唆している可能性 があると結論された。

本論文の要旨は第42回日本医学放射線学会総会, 第 22,23 回日本核医学会総会および第24回日本肺癌学会総 会において報告した。

\section{文献}

1）下里幸雄：肺癌の形態と，進展様式・予後・機 能との関係. 肺癌, $20: 3-20,1980$.

2) 小松彦太郎：肺腺癌の術後予後に関する検討. 肺癌, $23: 33-44,1983$.

3) Linder, M.C., Wright, K., Madara, J. : Concentration, structure and iron saturation of ferritins from normal human lung and lung tumors with graded histopathology. Enzime, 27 : 189-198, 1982.

4) Ker, K.M., Robertson, A.M.G., Lamb, D. : In vitro thymidine labelling of human pulmonary neoplasmas. Br. J. Cancer, 47 : 245252, 1983.

5) Edwards, C.L., Hayes, R.L. : Tumor scanning with ${ }^{67} \mathrm{Ga}$-citrate. J. Nucl. Med, 10 : 103-105, 1969.

6) Cox, P.H., Belfer, A.J., Pompe, W.D. : Thallium 201 chloride uptake in tumors, a possible complication in heart scintigraphy. $\mathrm{Br}$. J. Radiol, 49 : 767-768, 1976.

7) Muranaka, A. : Accumulation of radioisotopes with tumor affinity II. Comparison of the tumor accumulation of ${ }^{67} \mathrm{Ga}$-citrate and ${ }^{201} \mathrm{Tl}$-chloride in vitro. Acta. Med. Okayama,
35( 2 ) : 85-101, 1981.

8）戸川貴史, 森谷浩史, 木田利之, 他：原発性肺 癌における ${ }^{67} \mathrm{Ga},{ }^{201} \mathrm{Tl}$ スャンの臨床的検討. 核医学，19：1045-1049，1982.

9) Deland, H.L., Sauerbrunn, B.J.L., Boyd, C., et al.: ${ }^{67} \mathrm{Ga}$-citrate imaging in untreated primary lung cancer : Preliminary report of cooperative group. J. Nucl. Med, 15:408411, 1974.

10) Bekerman, C., Hoffer, P.B., Bitran, J.D., et al. : Gallium-67 citrate imaging studies of the lung. Seminars in Nucl. Med, $10: 286-301$, 1980.

11) Wolfson, R.J.: The diagnosis of bronchogenic carcinoma. Ann. Oto-Rhino Laryng, $70: 677-688,1961$.

12) Tsuboi, E., Ikeda, S., Tajima, M., et al. : Transbronchial biopsy smear for diagnosis of peripheral pulmonary carcinomas. Cancer, $20: 687-698,1967$.

13) Ellis, J.H.: Transbronchial lung biopsy via the fiberoptic bronchoscope. Chest, 68 : 524532, 1975.

14) Hayata, Y., Oho, K., Ichiba, M.: Per- 
cutaneus pulmonary puncture for cytologic diagnosis-Its diagnostic value for small peripheral pulmonary. Acta. Cytol, 17:469475, 1973.

15）下里幸雄：新内科学大系。28巻 $\mathrm{A}$ 肺腫瘍（吉 利 和, 他編), 中山書店, 東京, 48頁, 1977 .

16) Siemsen, J.K., Grebe, S.F., Waxman, A.D. : The use of Gallium-67 in pulmonary disorders. Seminars in Nucl. Med, $13: 235-249$, 1978.

17) Salvatore, M. , Carratu, L. , Porta, E. : Thallium-201 as a positive indicator for lung neoplasmas : Preliminary experiments. Radiol, 121 : 487-488, 1976.

18）利波紀久, 松田博史, 利波久雄, 他：肺腫瘍： ガリウム, 夕リウム。臨床放射線, $26 ： 745^{-}$ 750, 1981.

19) Hisada, K., Tonami, N., Miyamae, T., et al. : Clinical evaluation of tumor imaging with ${ }^{201}$ Tl chloride. Radiol, 129: 497-500, 1978.

20) Ito, Y., Muranaka, A., Harada, T., et al.: Experimental study on tumor affinity of 201 Tl-chloride. Eur. J. Nucl. Med, $3: 81-86$, 1978.

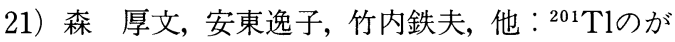
んおよび藏器親和性. Radioisotopes, 29：2227, 1980 .

22) Thesingh, C.W., Driessen, O.M. J., Daems, W. Th., et al: Accumulation and localization of gallium-67 in various types of primary lung carcinoma. J. Nucl. Med, 19:28-30, 1978.

23) Higashi, T., Wakao, H., Nakamura, K., et al.: Quantitative gallium-67 scanning for predictive value in primary lung carcinoma. J. Nucl. Med, 21 : 628-632, 1980.

24) Togawa, T.: A new classification of lung cancer from a nucleomedical viewpoint using quantitative ${ }^{201} \mathrm{Tl}$ and ${ }^{67} \mathrm{Ga}$ scans in relation to histological type. Fukushima J. Med. Sci, 30:39-61, 1984.

25）戸川貴史，鈴木 晃，加藤和夫，他：原発性肺 癌における ${ }^{201} \mathrm{Tl},{ }^{67} \mathrm{Ga}$ スキャンの定量的評価と 組織型との関連について。肺癌, $23: 387$, 1983.

26) Beebe, S.P.: The chemistry of malignant growths II-The inorganic constitutents of tumors. Am. J. physiol, $12: 167-172,1905$.

27) Waterhous, C., Terepka, A.R., Sherman, C. D.: The gross electrolyte composition of certain human malignant tissues. Cancer Res, 15 : 544-549, 1955.

28) Larson, S.M., Rasey, J.S., Allen, D.R., et al. : Common pathway for tumor cell uptake of Gallium-67 and Iron-59 via a transferrin receptor. J. Natl. Cancer Inst, 64 : 41-53, 1980.

29) Hayes, R.L., Rafter, J.J., Byrd, V.L., et al. : Studies of the in vivo entry of Ga-67 into normal and malignant tissue. J. Nucl. Med, 22 : 325-332, 1981. 


\title{
${ }^{201}$ TI to ${ }^{67}$ Ga Crude Uptake Ratio in Primary Lung Cancer with Reference to Histoligical Type
}

\author{
T. Togawa, A. Suzuki, Y. Higuchi, \\ K. Kato, K. Kobayashi and K. Kimura* \\ Departments of Nuclear Medicine and *Radiology, \\ Fukushima Medical School
}

${ }^{201} \mathrm{~T} 1$ to ${ }^{67} \mathrm{Ga}$ Crude Uptake Ratio (CUR) was measured in 40 patients with primary lung cancer using quantitative ${ }^{201} \mathrm{~T} 1$ and ${ }^{67} \mathrm{Ga}$ scans, and their CURs were compared with histological types. After regions of interest (ROIs) were set on the tumor and the normal lung, the mean counts ( $\mathrm{T}$ : at the tumor, $\mathrm{N}$ : at the normal lung) for ROIs were measured on both scans, and the CUR of ${ }^{201} \mathrm{~T} 1$ to ${ }^{67} \mathrm{Ga}$ (both crude uptakes: $\mathrm{T}-\mathrm{N} / \mathrm{N})$ was calculated on the same patients. Seventeen adenocarcinomas had a high CUR of $1.82 \pm 1.27$, many of them taking up more ${ }^{201} \mathrm{~T} 1$ than ${ }^{67} \mathrm{Ga}$. Fourteen epidermoid carcinomas had a significantly lower CUR of $0.41 \pm 0.25$ than adenocarcinoma $(\mathrm{p}<0.001)$, taking up more ${ }^{67} \mathrm{Ga}$ than ${ }^{201} \mathrm{~T} 1$. Compared with adenocarcinomas, 3 oat cell carcinomas also had a significantly lower CUR of $0.40 \pm 0.07(p<0.001)$, a value similar to epidermoid carcinoma. On the other hand, 2 adenosquamous carcinomas had a CUR of $0.95 \pm 0.19$, intermediate between adenocarcinoma and epidermoid carcinoma. The 40 patients with lung cancer were generally classified into the following 3 groups by CUR: Group I, ${ }^{67} \mathrm{Ga}$ uptake greater than ${ }^{201} \mathrm{~T} 1$ uptake (CUR<0.80). Group II, no definite difference between two uptakes $(0.80 \leqq$ CUR $<1.25)$, Group III, ${ }^{201} \mathrm{~T} 1$ uptake greater than ${ }^{67} \mathrm{Ga}$ uptake (CUR $\geqq 1.25$ ). Many epidermoid carcinomas and small cell carcinomas belonged to Group I, whereas many adenocarcinomas belonged to Group III. Furthermore, the 40 patients showed a continuous distribution from low-CUR epidermoid carcinoma to high-CUR adenocarcinoma. It was found that the measurement of ${ }^{201} \mathrm{~T} 1$ to ${ }^{67} \mathrm{Ga}$ Crude Uptake Ratio by tumors enables not only a quantitative estimation of lung cancer but a presumption of various histogeneses in lung cancer. 